\title{
Change and consequence
}

\section{In a second concluding article, Peter Pockley looks at Australian science and the recent election.}

\begin{abstract}
SCIENCE was not a starter in the public campaigning for the December election although there was plenty of activity behind the scenes. The Liberal Party did, however, make three mentions of science which were important in the light of subsequent events. This made the score Liberals 3, Labour 0 , for the Labour campaign concentrated on dramatising the constitutional issue of the powers of the Senate and the essentially political actions of the Governor General in bringing down the popularly clected government.
\end{abstract}

The first mention came in $\mathrm{Mr}$ Fraser's policy speech, in which, as an item of evidence for ineptness in the Labour administration, he took a passing swipe at the research grants controversy. The second item was the Liberal Party's issuing of a statement on science policy in which the Department of Science retained a central role. $\mathrm{Mr}$ Fraser's acceptance of any science policy is a political turn-around. In 1968, as Minister for Education and Science, he had argued in a major speech before an Academy of Science meeting that attempts to define a science policy were futile. This volte face paled into insignificance, though, before some others which $\mathrm{Mr}$ Fraser underwent but which he successfully played down during the campaign: he had, for instance, been one of the strongest advocates and administrators of compulsory military service and of the ultimately futile expedition by Australian forces, including conscripts, to the Vietnam war, policies which he could not afford to embrace in 1975 .

Mr Fraser got away with such inconsistencies by developing a form of nonspeak which he used successfully to deflect all specific questions with varying combinations of a few generalised, qualified or conditional phrases. This technique, which tied him down to almost no action of detail or permanent substance, was aggravating in the extreme to working journalists and political opponents alike, but such was the strength of feeling he generated against Labour that he had no cause for deigning to answer questions with facts or commitments. An example of this approach was provided by the third mention of science in the campaign.

Only five days before the election, Mr Fraser personally issued a statement designed to quell speculation that the Australian Science and Technology Counoil (ASTEC) would be abandoned or greatly modified by a Liberal government which had arisen from some remarks on a radio programme by the then Liberal spokesman on science, $\mathrm{Mr}$ Eric Robinson. The statement largely affirmed the objectives defined for ASTEC by Labour (although not by name, of course) and went on to say that it will report directly to the Prime Minister. This plan was welcomed by many scientists who had not been happy with Labour's arrangement in which ASTEC reported to the Minister for Science and Consumer Affairs. This much, at least, of $\mathrm{Mr}$ Fraser's statement calmed troubled spirits who felt even more secure from the statement that ASTEC "will be a body of the highest status and greatest independence".

It seems to have been only after the election that observers realised that the statement quoted gave no guarantee of independence, except in the way that that term may be defined by a conservative government. Labour was guaranteeing independence for ASTEC by making it a statutory corporation operating under its own Act of Parliament and requiring it to publish its findings. The necessary legislation was, however, one of many important Labour Bills already under debate but which were nullified by the proroguing of Parliament. ASTEC has, in fact, been operating only on an officially "interim" basis.

What happens to ASTEC now is a matter of guesswork. The small organisation has been transferred to the responsibility of the Prime Minister. The Chairman of the Interim body, $\mathrm{Dr} \mathbf{J}$. A. L. Matheson, has left his job as Vice-Chancellor of Monash University in anticipation of early confirmation as full-time Chairman. At the time of writing, if the government is acting on the matter at all, it is doing so with sealed lips. The longer the delay, the greater the speculation that "greatest independence" may mean becoming a box in the organisational chart of the Prime Minister's Department or the Department of Science and being treated as a kind of bureau.

\section{Science department curtailed}

No group in the public service would probably be happier with a diminution of ASTEC's independence than the Department of Science, which had never been enthusiastic about ASTEC as a rival in the advisory stakes to government. The department, however, lost much and gained nothing in terms of responsibilities after the election. For a few brief months of potential glory in 1975, the department had

\section{Sorry, for copyright reasons some images on this page may not be available online} \section{$\frac{2}{4}$
$\ddot{0}$
0
0
$\frac{0}{2}$}

James Webster (top) and Clyde Cameron

taken on an extra function of considerable political importance. For some time previously, Mr William Morrison had paved the way for his department to fly the popular flag of consumerism. On taking over $\mathrm{Mr}$ Morrison's portfolio, $\mathrm{Mr}$ Clyde Cameron was presented with the grander title of Minister for Science and Consumer Affairs. $\mathrm{Mr}$ Cameron made a rather ungainly start; his set-piece speeches cast grapeshot at many targets and displayed little sympathy with his new responsibilities. But, to his credit, he soon settled down to becoming a convinced champion of science per se. which $\mathrm{Mr}$ Morrison had never done.

In the consumer field, he secured a promise of services from $\mathrm{Mr}$ Ralph Nader. Substantial legislative powers were being developed by the new Consumer Protection Division of the department which had been given responsibility of the consumer sections of the forceful Trade Practices Act. In a trade-off with the Attorney General's Department which had thereby lost part of the administration of this Act, the Science Department handed over its Patents operations. Earlier in 1975, the Science Department had established a Consumer Standards Branch. In Mr Cameron's short reign, then, his department enjoyed both a monitoring and prosecuting function in the interests of consumers. This useful union 
of powers never enjoyed active consummation; if it had, there is little doubt that it was a potential votewinner for Labour.

In the December shuffle of responsibilities by $\mathrm{Mr}$ Fraser, all consumer activities were removed from Science and split between Attorney General's (consumer protection) and a new Department of Business and Consumer Affairs (consumer standards) where it will require devilish determination to prevent a conflict of interest between business and consumers, to the likely detriment of the latter. Patents, incidentally, continue to bounce around; their administration has now gone from Attorney General's to Business and Consumer Affairs. The fate of consumerism under the Liberals mirrors that of environmentalism which has similarly been buried within a large department of diverse interests, namely Environment, Housing and Community Affairs.

Also after the election, the Department of Minerals and Energy was renamed National Resources under the National Country Party Leader and Deputy Prime Minister, $\mathrm{Mr}$ Doug Anthony, as Minister. Professor Messel and Sir Lenox Hewitt retain influence in the department's area of responsibility through the Australian Atomic Energy Commission (AAEC), of which Sir Lenox is Vice-Chairman. Two of the five places on the AAEC have been vacant for some time. $\mathrm{Mr}$ Connor was probably keeping his empire-building options open; one of these options was thought to be the creation of a new multi-energy research and development authority which would have incorporated the AAEC, the Bureau of Mineral Resources and the Mineral Research Laboratories of CSIRO, all of which were then under Mr Connor's control. Mr Anthony has not held on to the CSIRO bit, and has shown no indication of how he will treat the AAEC.

The disciplined control on information within the Fraser ministry meant that it was not until some time after the election that the most senior people in CSIRO could obtain clarification of the line of responsibility of their organisation. The new Science Minister, Senator Webster, is now solely responsible for the Science and Industry Act which gives CSIRO its statutory independence. The MinisterCSIRO line is direct and separate from the Minister-Department line. In the face of diminished duties, the Science Department is not out of the woods yet; it will have to work hard to maintain its position which could be called into question whenever $\mathrm{Mr}$ Fraser reshuffles his Cabinet or when its Secretary reaches retiring age within a couple of years.
Senator Webster himself is somewhat of an unknown quantity. Before his elevation to the ministry, he was known only to the public through having survived a legal challenge to his eligibility to sit in Parliament on grounds of alleged improprieties in dealings between a family company and the government. Since coming to office, Senator Webster has made only the odd routine announcement on behalf of the organisations under him. $\mathrm{He}$ is not yet known for having a personal interest in science. However green a minister he may appear at the moment to senior Australian scientists, he is no different in pre-knowledge of scientific affairs from either of his Labour predecessors, and given his parliamentary reputation as a diligent worker on committees, Senator Webster should make something of his job in a stable political environment.

\section{Labour's heritage}

If nothing else, the political awakening

\section{Ringing the changes}

Australian science did not escape the impact of the country's political hiatus, as shown by this summary, covering in order the changes over the period beginning a few days before the election:

- The Science Task Force of the Royal Commission on Australian Government Administration recommended abolition of the Department of Science, and redistribution of its functions among other departments. - $\mathrm{Mr}$ Fraser, the second former Minister for Education and Science in a Liberal Government to become Prime Minister (the first was $\mathrm{Mr}$ John Gorton), won an outstanding victory, helped by a long-standing imbalance in size of electorates in favour of the conservative partiesLabour received $43 \%$ of votes but gained only $25 \%$ of seats.

- The first Labour Minister for Science, Mr Bill Morrison (later Minister for Defence) lost his seat by a handful of votes. The second, and last Labour Minister for Science (and Consumer Affairs), $\mathrm{Mr}$ Clyde Cameron, retained his seat and immediately lambasted $\mathrm{Mr}$ Whitlam for his leadership (which had led to the demotion of $\mathrm{Mr}$ Cameron to the Science portfolio).

- Mr Fraser appointed Senator James Webster, of the National Country Party, as Minister for Science, the portfolio which has the lowest seniority. The Department of Science remained in existence, but without consumer affairs.

- The Department of the Environment, another Labour-initiated de- of Australia under Labour has produced a quality of information and debate about science policy which is likely to work to the benefit of Australian science in the long run. On a more universal plane, the thoughtful, informed and voluminous reports issued recently, and the subsequent arguments about the very necessity for a Department of Science in any national government, are worthy of separate analysis outside the election context, for the factors involved for science planning may well prove to have global validity.

On the Australian scene, after five years of almost stand-still operations while awaiting times of enlightenment in science policy, it is sad to reflect that the arrival of these very times has coincided with a period of tight-fisted, inflation-dominated management of the economy. Australian scientists had deserved a better deal from both parties; but perhaps they were simply too nice and soft for too long.

partment, was abolished and its staff absorbed and reorganised under the umbrella of the new Department of Environment, Housing and Community Development. This department also embraced the Labourestablished Department of Urban and Regional Development. Its Minister is Senator Ivor Greenwood, a hard-line conservative.

- The Secretary of the Department of Science, Sir Hugh Ennor, publicly castigated the Task Force's recommendation that his department be abolished, saying it "lacked credibility" and "questionable logic".

- The Australian Academy of Science was publicly drawn into the debate about the usefulness of the Department of Science through the release of its submission to the Task Force. In appealing with feeling for stability in organisation and financing of science, the Academy concentrated on strengthening the advisory roles to government of the Academy itself and the Australian Science and Technology Council (ASTEC); the Academy mentioned the Department only in passing.

- The CSIRO was returned from a dual responsibility to Labour's Minister for Science and Consumer Affairs and Minister for Minerals and Energy to a single Minister for Science under the Liberals.

- The election by staff of a member of the CSIRO Executive, a mild attempt by Labour at worker participation, was stopped in mid-flight just before nominations closed. Official reason--to give time for reexamination of the implications. 